\title{
The role of vanilloid receptor type 1 (TRPV1) in hyperalgesia related to bovine digital dermatitis
}

\author{
Yuri S. Bonacin, ${ }^{1 *}$ Isabela C. S. Marques, ${ }^{2}$ Sérgio B. Garcia, ${ }^{2}$ Samara B. G. Silva, ${ }^{1}$ Paulo A. Canola, ${ }^{1}$ \\ and José A. Marques ${ }^{1}$ \\ ${ }^{1}$ Department of Clinical and Surgery, São Paulo State University (UNESP), School of Agricultural and Veterinarian Sciences, Jaboticabal, \\ São Paulo, Brazil 14884-900 \\ ${ }^{2}$ Department of Pathology and Legal Medicine, Ribeirão Preto School of Medicine, São Paulo University, Ribeirão Preto, São Paulo, \\ Brazil 14049-900
}

\section{ABSTRACT}

Bovine digital dermatitis is a contagious and chronic disease affecting the digits of dairy cattle worldwide. Tissue degradation may alter ionic channels and further activate vanilloid channels, more specifically the vanilloid receptor type 1 (TRPV1) that can generate and modulate hyperalgesia in cows affected with bovine digital dermatitis. The aim of this pilot study was to identify and quantify TRPV1 channels in dairy cows presenting with different stages of bovine digital dermatitis and compare these data according to the disease evolution and degree of hyperalgesia described in previous studies. Biopsies were taken from 15 lactating Holstein cows (23 lesions), and immunochemistry was performed to identify the number of TRPV1 fibers in the $4 \mathrm{M}$-stages of digital dermatitis and the control group. This pilot study had 5 experimental groups, M1 (5 samples), M2 (5 samples), M3 (4 samples), M4 (4 samples), and the control group (5 samples), with inclusion criteria was the presence of a bovine digital dermatitis lesion in at least one digit. The pilot results demonstrate an increase in expression of TRPV1 receptors in group M4 in comparison with the other groups. Bovine digital dermatitis may cause an increase in expression of TRPV1 receptors in the chronic stages of the disease, possibly contributing to the hyperalgesia described in affected animals; nevertheless, further research is needed to define this relation.

Key words: capsaicin, chronic, hoof, lameness, pain

\section{INTRODUCTION}

Bovine digital dermatitis (BDD) was first described in 1974, in Italy (Cheli and Mortellaro, 1974), as a very

\footnotetext{
Received May 29, 2019.

Accepted March 31, 2020.

*Corresponding author: ysbonacin@gmail.com
}

painful foot lesion causing varying degrees of lameness. Its occurrence is increasing among dairy cows worldwide. The disease is responsible for the largest economic costs associated with foot disorders in cattle (Evans et al., 2016). Animal welfare is also significantly affected because locomotion is severely impaired by the disease (Bruijnis et al., 2010), leading to culling, reproductive losses, and decrease in milk production (Warnick et al., 2001; Bruijnis et al., 2010).

Diseases and other stimuli, such as mechanical trauma, inflammatory processes, temperature changes, and $\mathrm{pH}$ changes, that induce pain in animals and humans are recognized by primary afferent neurons, called nociceptors. These nociceptors modulate and transmit the stimuli to the central nervous system by some afferent fibers: mostly unmyelinated $\mathrm{C}$ fibers, and myelinated $\mathrm{A} \delta$ and $\mathrm{A} \beta$ (Caterina and Julius, 2001; Levine, 2018).

Along with severely painful conditions in people, dogs, and mice such as chronic dermatitis and neoplasia (Caterina et al., 1997; Karai et al., 2004; Gopinath et al., 2005; Ehnis-Pérez et al., 2016), BDD causes modifications in the tissue structures of the hoof that can lead to local rearrangement of ionic channels in the skin, increasing transmission and modulation of pain pathways. A specific ionic channel receptor, named vanilloid, was described by Caterina et al. (1997). These vanilloid receptors can be triggered by extreme temperatures $\left(>43^{\circ} \mathrm{C}, 109.4^{\circ} \mathrm{F}\right)$ or low $\mathrm{pH}(<6$; Caterina, 2014). A specific type-1 vanilloid receptor (VR1) has been grouped in the potential transient receptor family and named TRPV1 (Caterina et al., 1997). The TRPV1 receptors have already been identified in a variety of tissue nerve endings, such as colonic wall (Kimball et al., 2004), skin, immune cells (Bodó et al., 2004; Caterina and Pang, 2016), and spinal cord of rats (Caterina et al., 1997). These receptors are widely distributed over the dermis and epidermis being identified on keratinocytes, smooth muscle of dermal vessels (Tóth et al., 2014), mast cells, neuroectodermal 
tissue, and other constituents of the skin of animals and humans (Bodó et al., 2004). Evidence indicates that the distribution of these on the human skin follows a pattern, and it has been proposed that these receptors may play an important role in skin homeostasis (Bodó et al., 2004). Pain stimuli are transmitted by nociceptor stimuli (mainly type $\mathrm{A} \delta$, myelinated axon and fast conduction fibers, and C, unmyelinated axons), reduceddiameter and low-conduction fibers that are responsible for prolonged pain sensation (hyperalgesia) (Dubin and Patapoutian, 2010). The TRPV1 are also responsible for cationic flux during pain modulation and conduction of type $\mathrm{A} \delta$ and $\mathrm{C}$ fibers, thus acting in acute and chronic pain (Caterina et al., 1997; Caterina and Julius, 2001; Morgan et al., 2019). In some diseases, such as contact dermatitis in mice, TRPV1 receptors were found to be increased in comparison to normal skin (Bánvölgyi et al., 2005). Conversely, diabetes promotes epidermal hyposensitivity, and patients were found to have a decreased number of TRPV1 receptors in the skin when compared with the normal group. Diabetes promotes less nerve growth factor, decreasing peripheral nervous system repair and promoting smaller TRPV1 expression. These results indicate that nociception and pain modulation could be influenced by TRPV1, which could be less present when the nerve loses or decreases regeneration capacity (Facer et al., 2007).

A higher expression of TRPV1 receptors can lead to an exaggerated response to a noxious stimulus. This is known as hyperalgesia or neurogenic inflammation (Patapoutian et al., 2009). In contrast, these receptors can be suppressed by some substances such as capsaicin, with marked decrease in hyperalgesia, demonstrating that vanilloid receptors play a role in transmission and modulation of pain (Caterina and Julius, 2001).

Studies with TRPV1 have shown that they can trigger sensory nerve impulses to modulate nociceptor response to pain (Moran et al., 2011). This nociceptor response could be initiated by exogenous or endogenous substances, chemical or physical stimuli acting in a different pain transmission pathway (Chávez et al., 2010) through a pre- or postsynaptic interaction (Doyle et al., 2002). Protons produced by infected, injured, inflamed, or ischemic tissue, and lipids, in which TRPV1 could be bonded to proinflammatory and inflammatory substances, are examples of the endogenous substances initiating nerve impulses (Tominaga et al., 1998; Caterina and Julius, 2001; Caterina, 2014).

The aim of this study was to evaluate the expression of vanilloid receptor type 1 in the skin tissue of dairy cows with BDD at different and distinct phases of the disease, to investigate its role in the hyperalgesia associated with the disease.

\section{MATERIALS AND METHODS}

\section{Data Description}

This cross-sectional study was conducted on a dairy farm with approximately 3,000 Holstein cows, located in São Paulo state, Brazil. The farm was milking around 1,500 animals housed in free stalls and fed a balanced diet. The manure was continuously removed by an automatic alley scraper. This farm was chosen due to its large size and, consequently, the high numbers of foot disorders. The study was approved and supervised by the institution's animal use and care committee (number $20067 / 15)$.

Fifteen Holstein cows in lactation, $4.4 \pm 1.45$ yr of age, diagnosed with BDD in its 4 distinct phases (M1, M2, M3, and M4) according to the M-stage scoring system described by Döpfer et al. (1997) and updated by Berry et al. (2012), were included in the study. The identification of the BDD lesions occurred during hoof trimming, based on macroscopic analysis (Döpfer et al., 1997; Berry et al., 2012), and are shown in Table 1. This procedure was always performed by a single qualified person who was also responsible for the identification and treatment of the hoof diseases. If a BDD lesion was identified, the subject information was recorded in an individual file, with the description of the lesion. Information regarding the affected digit(s), anatomical distribution of the lesion(s), and the clinical stage were recorded. The inclusion criterion was the presence of a BDD lesion in at least one digit. The animals were distributed into 5 experimental groups: control group $(\mathbf{S})$ consisting of healthy subjects and the other 4 assigned based on Döpfer et al. (1997) M-stage classification of the lesion: early stages of the lesion (M1), classic ulcerative lesion (M2), healing stage (M3), and chronic stage (M4).

\section{Lesion Samples}

Initially, the digits, interdigital spaces, and the spaces between the heel bulbs were thoroughly cleaned with sodium chloride $0.9 \%$ solution (Eurofarma Laboratory S.A., São Paulo, SP) and dried with paper towels. Then, the spaces between the heel bulbs were inspected for identification of BDD lesions. Tissue samples were collected at the center of the BDD lesions using a 4-mm sterile punch (Brasmed, Paulínia, SP, Brazil) and immediately placed in sterile tubes containing $7 \mathrm{~mL}$ of $10 \%$ formalin buffered solution and classified according to the M-stage (adapted from Evans et al., 2008). Samples of healthy tissue were randomly collected from healthy hooves of 5 dairy cows (control group). From 
Table 1. Biopsies from 15 Holstein cows with 4 bovine digital dermatitis stages and healthy tissue, sampled to perform immunohistochemistry and vanilloid receptor type 1 count

\begin{tabular}{lcll}
\hline $\begin{array}{l}\text { Animal } \\
\text { ID }\end{array}$ & $\begin{array}{c}\text { Number of } \\
\text { samples }\end{array}$ & M-stage & $\begin{array}{l}\text { Affected } \\
\text { hoof }^{2}\end{array}$ \\
\hline 1 & 2 & M4 & LHL \\
& & S & RHL \\
2 & 1 & M1 & RFL \\
3 & 2 & M2 & RFL \\
4 & & M3 & LFL \\
& 2 & M1 & RHL \\
5 & 1 & S & LHL \\
6 & 1 & M1 & LFL \\
7 & 1 & M1 & RFL \\
8 & 2 & M2 & RHL \\
9 & & S & LFL \\
10 & 1 & M2 & RHL \\
& 3 & M2 & RFL \\
11 & & M3 & LFL \\
12 & & M4 & RHL \\
13 & & M3 & RHL \\
14 & 1 & M4 & LHL \\
15 & 1 & M2 & RFL \\
& 1 & M3 & LFL \\
& 2 & S & RHL \\
\hline & 2 & M4 & RHL \\
\hline
\end{tabular}

${ }^{1} \mathrm{~S}=$ control group; M1 = early stages of the lesion; M2 = classic ulcerative lesion; M3 = healing stage; and M4 = chronic stage.

${ }^{2} \mathrm{LHL}=$ left hindlimb; RHL = right hindlimb; LFL = left forelimb; $\mathrm{RFL}=$ right forelimb.

the 15 cows, a single sample was taken from each lesion according to the M-stage presented. If the cow had lesions in multiple feet, samples were collected from each of these; thus, the number of samples varied between cows. Groups S, M1, and M2 contained 5 lesion samples each; groups M3 and M4 contained 4 samples each. The material was sent to the Forensics Medical Center of a collaborating School of Medicine for analysis.

\section{Histopathology and Immunocytochemistry}

Samples were removed from formalin solution and submitted to alcohol dehydration (from $70 \%$ to absolute alcohol) before analysis. The material was rinsed with xylene $(100 \%)$ and embedded in paraffin. Transversal histological sections of $4 \mu \mathrm{m}$ were cut and fixed in glass slides that were heated at $60^{\circ} \mathrm{C}$ for $75 \mathrm{~min}$. The slides were dewaxed using xylene and rehydrated to increase water concentration before microscopic analysis. Finally, the antigenic recovery was carried out with physico-chemical method by using citrate buffer $(\mathrm{pH}$ 6.0) for $20 \mathrm{~min}$. Microscopic analysis was performed by a single qualified professional to avoid bias in the interpretation of the results.

The slides were stained with hematoxylin/eosin and microscopically analyzed. Histopathologic examination was conducted to diagnose and stage BDD as described by Rebhun et al. (1980), Borgmann et al. (1996), and Rasmussen et al. (2012).

After the histopathologic examination, immunohistochemistry was performed to identify and count the type 1 vanilloid receptors. To that purpose, the glass slides were exposed to hydrogen peroxide (3\%) and horse serum at 1:10 dilution in PBS ( $\mathrm{pH} 7.4$ ), then washed 3 times with PBS before incubation with primary mouse antibody directed against TRPV1 receptor code MAB5568 (Chemicon/Millipore, Bedford, MA) at 1:1,500 dilution. Glass slides were rinsed with PBS once again to remove excess primary antibody and then incubated with secondary biotinylated antibody PicTure-MAX Polymer Detection kit (Invitrogen, Carlsbad, CA). Glass slides were incubated with conjugated polymer for another $30 \mathrm{~min}$. Subsequently, samples were placed in $3,3^{\prime}$-diaminobenzidine chromogen solution for 1 to 3 min until a brown precipitation appeared. The slide was counterstained with diluted Harris hematoxylin for 1 min, dehydrated, and diaphanized one more time. Entellan (Merckur, Armstard, Germany) was used for tissue glass slide assembly.

\section{TRPV1 Fiber Quantification}

The immunostained samples were than examined by optic microscopy (Axiostar plus, Zeiss, Oberkochen, Germany) to quantify the TRPV1 receptors. The number of fibers in a total of 20 frames was counted. Then, the total number of fibers was divided by the number of frames to obtain the mean value for each immunostained sample. Images were also captured by microscopic camera while the evaluator was counting the fibers.

\section{Statistical Analysis}

Statistical analysis was performed using the R Statistical Software (Development Core Team, Vienna, Austria). Data were initially submitted to ShapiroWilk normality test. Variables with nonparametric distribution were transformed into a logarithmic scale $[\log ($ obs. +1$)]$ for analysis, where obs. = observations. Post-hoc Tukey's test was implemented following multiple pairwise comparison analysis. The level of significance was set at $P \leq 0.05$.

\section{RESULTS}

Fifteen Holstein cows from a dairy farm in Brazil were analyzed, and biopsies of all M4 stages of BDD and healthy tissue were taken using the method described 
earlier. No M4.1 stage was found during the study and the sampled animals are described in Table 1.

The histopathology exam was performed only for the positive control, where the macroscopic aspect of lesions was consistent with microscopic findings in other studies (Rebhun et al., 1980; Borgmann et al., 1996; Rasmussen et al., 2012). Subsequently, the immunohistochemical analysis was executed using the described mouse antibody against the TRPV1 receptor. The antibody reacted effectively with the bovine TRPV1 receptors (Figure 1).

Image analysis and fiber count were performed in 5 samples from groups S, M1, and M2, and 4 from each of the other groups, M3 and M4, for a total of 23 biopsies as shown in Table 2 . The mean $( \pm \mathrm{SD})$ was $0.12( \pm 0.04)$ in the S group, $0.16( \pm 0.13)$ in M1, $0.24( \pm 0.19)$ in M2, $0.40( \pm 0.29)$ in M3, and $3.05( \pm 1.16)$ in M4.

The TRPV1 immunostained fibers increased in proportion with the M-stage of $\mathrm{BDD}$; samples from the more chronic M4 stage had more TRPV1 $(P<0.001)$ when compared with the other groups (Table 2 ).

\section{DISCUSSION}

Since TRPV1 fibers were first reported by Caterina et al. (1997), there have been improvements in our understanding of induction and modulation pathways of pain through stimulation of afferent fibers (Tominaga et al., 1998; Morgan et al., 2019). One of the main clinical signs associated with BDD is chronic and severe lameness (Cheli and Mortellaro, 1974; Warnick et al., 2001; Green et al., 2002; Bicalho et al., 2007; Orsel et al., 2018). Receptors such as TRPV1 could be involved in the induction and modulation of pain, thus producing hyperalgesia in BDD-affected cattle; moreover, lameness was a typical feature among the animals with disease in this study.

To date, the role of nociceptive stimulus in BDDassociated pain at the different stages of the disease has not yet been thoroughly understood. A single study was done in which the authors compared the differences in nociceptive threshold of healing and healed lesions (Cutler et al., 2013), and according to the authors, active lesions have a lower threshold when compared with healed lesions. Active lesions such as the ones observed in M1 and M2 stages of BDD may predispose to an exacerbated inflammatory process (Capion et al., 2018), and as a consequence, to a rearrangement of pain receptors, thus increasing TRPV1 over the chronic stages of the disease (M4-stage). This would explain our results (Table 2). Furthermore, lameness has been noted to be more prominent in the chronic stages of the disease due to changes in the lesion that can be observed macroscopically (Krull et al., 2016; Plummer and Krull,

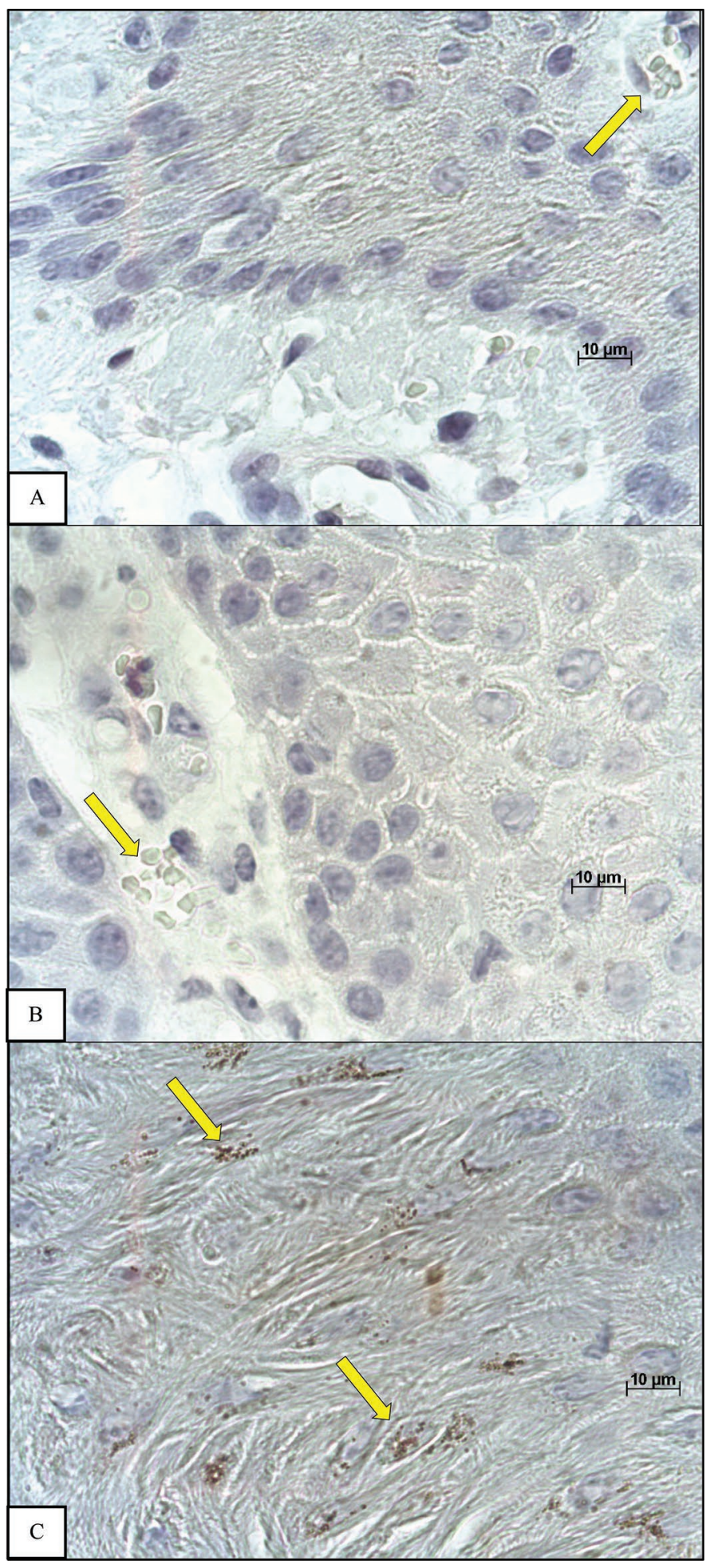

Figure 1. Vanilloid receptor type 1 (TRPV1) immunoassayed fibers (yellow arrow) on healthy skin sample (A), M2 stage of classical ulcerative bovine digital dermatitis (B), and chronic M4 stage, with higher concentration of TRPV1 fibers in comparison to the other groups $(\mathrm{C})$. 
Table 2. Distribution of vanilloid receptor type 1 (TRPV1) immunoassayed fiber numbers in the healthy control group (S) and in bovine digital dermatitis M-stage groups M1, M2, M3, and M4

\begin{tabular}{|c|c|c|c|c|c|c|c|}
\hline \multirow{2}{*}{$\frac{\text { Group }^{1}}{\mathrm{~S}}$} & \multicolumn{5}{|c|}{$\begin{array}{c}\text { Sample identification } \\
\text { (mean of immunostained fiber count in } 20 \text { frames/sample) }\end{array}$} & \multirow{2}{*}{$\begin{array}{c}\begin{array}{c}\text { No. of } \\
\text { samples }\end{array} \\
5\end{array}$} & \multirow{2}{*}{$\begin{array}{c}\text { TRPV1 } \\
(\text { mean } \pm \text { SD })\end{array}$} \\
\hline & $\begin{array}{l}\mathrm{S} 1 \\
(0.1)\end{array}$ & $\begin{array}{l}\text { S2 } \\
(0.1)\end{array}$ & $\begin{array}{l}\text { S3 } \\
(0.1)\end{array}$ & $\begin{array}{l}\mathrm{S} 4 \\
(0.2)\end{array}$ & $\begin{array}{l}\text { S5 } \\
(0.1)\end{array}$ & & \\
\hline M1 & $\begin{array}{c}\text { M1.1 } \\
(0.1)\end{array}$ & $\begin{array}{c}\mathrm{M} 1.2 \\
(0.1)\end{array}$ & $\begin{array}{c}\text { M1.3 } \\
(0.1)\end{array}$ & $\begin{array}{c}\mathrm{M} 1.4 \\
(0.4)\end{array}$ & $\begin{array}{c}\mathrm{M} 1.5 \\
(0.1)\end{array}$ & 5 & $0.16 \pm 0.134^{\mathrm{a}}$ \\
\hline M2 & $\begin{array}{r}\text { M2.1 } \\
(0.1)\end{array}$ & $\begin{array}{r}\text { M2.2 } \\
(0.4)\end{array}$ & $\begin{array}{r}\mathrm{M} 2.3 \\
(0.1)\end{array}$ & $\begin{array}{r}\mathrm{M} 2.4 \\
(0.1)\end{array}$ & $\begin{array}{r}\mathrm{M} 2.5 \\
(0.5)\end{array}$ & 5 & $0.24 \pm 0.194^{\mathrm{a}}$ \\
\hline M3 & $\begin{array}{l}\text { M3.1 } \\
(0.4)\end{array}$ & $\begin{array}{r}\text { M3.2 } \\
(0.8)\end{array}$ & $\begin{array}{l}\text { M3.3 } \\
(0.3)\end{array}$ & $\begin{array}{c}\text { M3.4 } \\
(0.1)\end{array}$ & - & 4 & $0.40 \pm 0.294^{\mathrm{a}}$ \\
\hline M4 & $\begin{array}{c}\text { M4.1 } \\
(3.2)\end{array}$ & $\begin{array}{r}\text { M4.2 } \\
(4.6)\end{array}$ & $\begin{array}{c}\text { M4.3 } \\
(1.9)\end{array}$ & $\begin{array}{c}\mathrm{M} 4.4 \\
(2.5)\end{array}$ & - & 4 & $3.05 \pm 1.162^{\mathrm{b}}$ \\
\hline
\end{tabular}

${ }^{\mathrm{a}, \mathrm{b}}$ Means within a column with different superscripts differ by Tukey's test $(P<0.001)$.

${ }^{1} \mathrm{M} 1$ = early stages of the lesion; M2 = classic ulcerative lesion; M3 = healing stage; and M4 = chronic stage.

2017). Presumptively, a redistribution of ionic channels could occur as a consequence of this process, as has been described by others with respect to species other than cattle (Ji et al., 2002; Bennett and Woods, 2014; Hsieh et al., 2017). In humans, some diseases such as diabetes could reduce the TRPV1 receptor number when compared with normal skin, reducing the pain sensation (Facer et al., 2007), and contact dermatitis in mice can increase the number of receptors (Bánvölgyi et al., 2005). We compared a BDD-positive sample lesion and a nonpositive sample, and the increase in TRPV1 observed in the chronic stage (M4) of the disease is an indicator that this specific receptor may play an important role in pain transmission in BDD-affected cows, potentially contributing to hyperalgesia and associated lameness. Regrettably, no M4.1 stage, as updated by Berry et al. (2012), could be found during the experimental period, but in further studies it could be an interesting group, as it presents one chronic M4 lesion and an active small lesion (Berry et al., 2012), which potentially could promote more TRPV1 proliferation. We could not score the lame cows and divided them in groups in order not to change the farm routine, so the individual's history and other concomitant diseases could not be obtained, which is a limitation of this pilot study; in this way, further research is needed to show the relationship between lameness score and TRPV1 receptor numbers.

Another limitation during sample collection was that it was not possible to get totally healthy animals for the study. As a result, the control group could also be affected by lesions in other legs. However, we assume that the samples from different legs are independent and the reaction we measured is correct.

The use of antibodies against TRPV1 (MAB5568, Chemicon) has been described in previous studies (Hermes et al., 2016; Marrone et al., 2017). According to the manufacturer's specifications, it has proven reactivity in rats, mice, and guinea pigs. To date, its reactivity against bovine tissue samples had not been described. Our immunohistochemistry results suggest that the use of commercial rat antibodies against TRPV1 in bovine skin samples is effective (Figure 1).

Activation of TRPV1 receptors may also be triggered by many extrinsic factors, such as low $\mathrm{pH}$ (Caterina et al., 1997). Because dairy cows are kept for long periods within the stall during milking, manure accumulates on the floor. As a consequence, the floor becomes acidic (McCaskey and Wang, 1983; Sánchez et al., 2000). Also, the direct contact of the manure with the digits may predispose cows to skin inflammation and local reduction of $\mathrm{pH}$ (Caterina, 2014). This local reduction in $\mathrm{pH}$, associated with the inflammatory process resulting from the BDD lesion, could trigger activation of TRPV1 receptors, thus contributing to the local hyperalgesia and ensuing lameness in dairy cows with BDD.

\section{CONCLUSIONS}

In this pilot study, TRPV1 receptors appear to increase in the chronic stages of BDD in dairy cattle. Thus, these receptors might play an important role in the pathogenesis of the disease associated with the transmission of pain. Activation and recruitment seem to be multifactorial. Nevertheless, a better understanding of its role in the disease with new studies could further lead to improvement in therapeutic strategies for pain modulation and control, thus providing better welfare for BDD-affected cows.

\section{ACKNOWLEDGMENTS}

The authors thank João Ademir de Oliveira (Department of Exact Sciences, São Paulo State University, Jaboticabal, Brazil) for helping us with statistical tests. This study was financed in part by the Coordenação de 
Aperfeiçoamento de Pessoal de Nível Superior-Brasil (CAPES), Finance Code 001. The authors have no conflicts of interest.

\section{REFERENCES}

Bánvölgyi, Á., L. Pálinkás, T. Berki, N. Clark, A. D. Grant, Z. Helyes, G. Pozsgai, J. Szolcsányi, S. D. Brain, and E. Pintér. 2005. Evidence for a novel protective role of the vanilloid TRPV1 receptor in a cutaneous contact allergic dermatitis model. J. Neuroimmunol. 169:86-96. https://doi.org/10.1016/j.jneuroim.2005.08.012.

Bennett, D. L., and C. G. Woods. 2014. Painful and painless channelopathies. Lancet Neurol. 13:587-599. https://doi.org/10.1016/ S1474-4422(14)70024-9.

Berry, S. L., D. H. Read, T. R. Famula, A. Mongini, and D. Döpfer. 2012. Long-term observations on the dynamics of bovine digital dermatitis lesions on a California dairy after topical treatment with lincomycin $\mathrm{HCl}$. Vet. J. 193:654-658. https://doi.org/10 $.1016 / j . t v j 1.2012 .06 .048$.

Bicalho, R. C., S. H. Cheong, G. Cramer, and C. L. Guard. 2007. Association between visual locomotion score and an automated locomotion score in lactating Holstein cows. J. Dairy Sci. 90:32943300. https://doi.org/10.3168/jds.2007-0076.

Bodó, E., I. Kovács, A. Telek, A. Varga, R. Paus, L. Kovács, and T. Bíró. 2004. Vanilloid receptor-1 (VR1) is widely expressed on various epithelial and mesenchymal cell types of human skin. J. Invest. Dermatol. 123:410-413. https://doi.org/10.1111/j.0022-202X.2004 .23209.x.

Borgmann, I. E., J. Bailey, and E. G. Clark. 1996. Spirochete-associated bovine digital dermatitis. Can. Vet. J. 37:35-37.

Bruijnis, M. R. N., H. Hogeveen, and E. N. Stassen. 2010. Assessing economic consequences of foot disorders in dairy cattle using a dynamic stochastic simulation model. J. Dairy Sci. 93(Suppl.1):2419-2432. https://doi.org/10.3168/jds.2009-2721.

Capion, N., E. K. Larsson, and O. L. Nielsen. 2018. A clinical and histopathological comparison of the effectiveness of salicylic acid to a compound of inorganic acids for the treatment of digital dermatitis in cattle. J. Dairy Sci. 101(Suppl. 1):1325-1333. https://doi.org/ $10.3168 /$ jds. $2017-13622$.

Caterina, M. J. 2014. TRP channel cannabinoid receptors in skin sensation, homeostasis, and inflammation. ACS Chem. Neurosci. 5(Suppl. 1):1107-1116. https://doi.org/10.1021/cn5000919.

Caterina, M. J., and D. Julius. 2001. The vanilloid receptor: A molecular gateway to the pain pathway. Annu. Rev. Neurosci. 24:487-517. https://doi.org/10.1146/annurev.neuro.24.1.487 http://dx.doi .org/0147-006X/01/0301-0487\$14.00.

Caterina, M. J., M. A. Schumacher, M. Tominaga, T. A. Rosen, J. D. Levine, and D. Julius. 1997. The capsaicin receptor: A heatactivated ion channel in the pain pathway. Nature 389:816-824. https://doi.org/10.1038/39807.

Caterina, M. J., and Z. Pang. 2016. TRP channels in skin biology and pathophysiology. Pharmaceuticals 9(Suppl. 4):77. https://doi.org/ 10.3390/ph9040077.

Chávez, A. E., C. Q. Chiu, and P. E. Castillo. 2010. TRPV1 activation by endogenous anandamide triggers postsynaptic long-term depression in dentate gyrus. Nat. Neurosci. 13(Suppl. 1):1511-1518. https://doi.org/10.1038/nn.2684.

Cheli, R., and C. M. Mortellaro. 1974. La dermatite digitale del bovino. Pages 208-213 in Proc. 8th International Meeting on Diseases of Cattle, Milan, Italy. Piacentina Gallarati, Piacenza, Italy.

Cutler, J. H. H., G. Cramer, J. J. Walter, S. T. Millman, and D. F. Kelton. 2013. Randomized clinical trial of tetracycline hydrochloride bandage and paste treatments for resolution of lesions and pain associated with digital dermatitis in dairy cattle. J. Dairy Sci. 96:7550-7557. https://doi.org/10.3168/jds.2012-6384.

Döpfer, D., A. A. H. M. ter Huurne, J. L. Cornelisse, A. J. A. M. van Asten, A. Koopmans, F. A. Meijer, Y. H. Schukken, I. Szakall, W. Klee, and R. B. Bosma. 1997. Histological and bacteriological evaluation of digital dermatitis in cattle, with special reference to spirochaetes and Campylobacter faecalis. Vet. Rec. 140:620-623. https://doi.org/10.1136/vr.140.24.620.

Doyle, M. W., T. W. Bailey, Y. H. Jin, and M. C. Andresen. 2002. Vanilloid receptors presynaptically modulate cranial visceral afferent synaptic transmission in nucleus tractus solitarius. J. Neurosci. 22:8222-8229. https://doi.org/10.1523/JNEUROSCI.22-18-08222 2002.

Dubin, A. E., and A. Patapoutian. 2010. Nociceptors: The sensors of the pain pathway. J. Clin. Invest. 120(Suppl.1):3760-3772. https:/ /doi.org/10.1172/JCI42843.

Ehnis-Pérez, A. B. Torres-Álvarez, D. Cortés-García, D. HernándezBlanco, C. Fuentes-Ahumada, and J. P. Castanedo-Cázares. 2016. Relationship between transient receptor potential vanilloid-1 expression and the intensity of sensitive skin symptoms. J. Cosmet. Dermatol. 15:231-237. https://doi.org/10.1111/jocd.12204.

Evans, N. J., J. M. Brown, I. Demirkan, R. D. Murray, W. D. Vink, R. W. Blowey, C. A. Hart, and S. D. Carter. 2008. Three unique groups of spirochetes isolated from digital dermatitis lesions in UK cattle. Vet. Microbiol. 130:141-150. https://doi.org/10.1016/ j.vetmic.2007.12.019.

Evans, N. J., R. D. Murray, and S. D. Carter. 2016. Bovine digital dermatitis: Current concepts from laboratory to farm. Vet. J. 211(Suppl.1):3-13. https://doi.org/10.1016/j.tvjl.2015.10.028.

Facer, P., M. A. Casula, G. D. Smith, C. D. Benham, I. P. Chessell, C. Bountra, M. Sinisi, R. Birch, and P. Anand. 2007. Differential expression of the capsaicin receptor TRPV1 and related novel receptors TRPV3, TRPV4 and TRPM8 in normal human tissues and changes in traumatic and diabetic neuropathy. BMC Neurol. 7:11. https://doi.org/10.1186/1471-2377-7-11.

Gopinath, P., E. Wan, A. Holdcroft, P. Facer, J. B. Davis, G. D. Smith, C. Bountra, and P. Anand. 2005. Increased capsaicin receptor TRPV1 in skin nerve fibres and related vanilloid receptors TRPV3 and TRPV4 in keratinocytes in human breast pain. BMC Womens Health 5:2-10. https://doi.org/10.1186/1472-6874-5-2.

Green, L. E., V. J. Hedges, Y. H. Schukken, R. W. Blowey, and A. J. Packington. 2002. The impact of clinical lameness on the milk yield of dairy cows. J. Dairy Sci. 85:2250-2256. https://doi.org/10 $.3168 /$ jds.S0022-0302(02)74304-X.

Hermes, S. M., M. C. Andresen, and S. A. Aicher. 2016. Localization of TRPV1 and P2X3 in unmyelinated and myelinated vagal afferents in the rat. J. Chem. Neuroanat. 72(Suppl.1):1-7. https://doi .org/10.1016/j.jchemneu.2015.12.003.

Hsieh, W.-S., C.-C. Kung, S.-L. Huang, S.-C. Lin, and W.-H. Sun. 2017. TDAG8, TRPV1, and ASIC3 involved in establishing hyperalgesic priming in experimental rheumatoid arthritis. Sci. Rep. 7:8870. https://doi.org/10.1038/s41598-017-09200-6.

Ji, R.-R., T. A. Samad, S.-X. Jin, R. Schmoll, and C. J. Woolf. 2002. p38 MAPK activation by NGF in primary sensory neurons after inflammation increases TRPV1 levels and maintains heat hyperalgesia. Neuron 36:57-68. https://doi.org/10.1016/S0896 -6273(02)00908-X.

Karai, L., D. C. Brown, A. J. Mannes, S. T. Connelly, J. Brown, M. Gandal, O. M. Wellisch, J. K. Neubert, Z. Olah, and M. J. Iadarola. 2004. Deletion of vanilloid receptor 1 expressing primary afferent neurons for pain control. J. Clin. Invest. 113:1344-1352. https://doi.org/10.1172/JCI20449.

Kimball, E. S., N. H. Wallace, C. R. Schneider, M. R. D'Andrea, and P. J. Hornby. 2004. Vanilloid receptor 1 antagonists attenuate disease severity in dextran sulphate sodium-induced colitis in mice. Neurogastroenterol. Motil. 16:811-818. https://doi.org/10.1111/j .1365-2982.2004.00549.x.

Krull, A. C., J. K. Shearer, P. J. Gorden, H. M. Scott, and P. J. Plummer. 2016. Digital dermatitis: Natural lesion progression and regression in Holstein dairy cattle over 3 years. J. Dairy Sci. 99(Suppl.1):3718-3731. https://doi.org/10.3168/jds.2015-10535.

Levine, T. D. 2018. Small fiber neuropathy: Disease classification beyond pain and burning. J. Cent. Nerv. Syst. Dis. 10:1179573518771703. https://doi.org/10.1177/1179573518771703.

Marrone, M. C., A. Morabito, M. Giustizieri, V. Chiurchiu, A. Leuti, M. Mattioli, S. Marinelli, L. Riganti, M. Lombardi, E. Murana, A. Totaro, D. Piomelli, D. Ragozzino, S. Oddi, M. Maccarrone, C. 
Verderio, and S. Marinelli. 2017. TRPV1 channels are critical brain inflammation detectors and neuropathic pain biomarkers in mice. Nat. Commun. 8:15292. https://doi.org/10.1038/ncomms15292.

McCaskey, T. A., and Y. D. Wang. 1983. Microflora and acid development of rations ensiled with varied percents of bovine manure and moisture. J. Dairy Sci. 66:93-98. https://doi.org/10.3168/jds .S0022-0302(83)81758-5.

Moran, M. M., M. A. McAlexander, T. Bíró, and A. Szallasi. 2011. Transient receptor potential channels as therapeutic targets. Nat. Rev. Drug Discov. 10(Suppl.1):601-620. https://doi.org/10.1038/ $\operatorname{nrd} 3456$.

Morgan, M., S. Nencini, J. Thai, and J. J. Ivanusic. 2019. TRPV1 activation alters the function of $\mathrm{A} \delta$ and $\mathrm{C}$ fiber sensory neurons that innervate bone. Bone 123(Suppl.1):168-175. https://doi.org/ 10.1016/j.bone.2019.03.040.

Orsel, K., P. Plummer, J. Shearer, J. DeBuck, S. D. Carter, R. Guatteo, and H. W. Barkema. 2018. Missing pieces of the puzzle to effectively control digital dermatitis. Transbound. Emerg. Dis. 65(Suppl.1):186-198. https://doi.org/10.1111/tbed.12729.

Patapoutian, A., S. Tate, and C. J. Woolf. 2009. Transient receptor potential channels: Targeting pain at the source. Nat. Rev. Drug Discov. 8(Suppl.1):55-68. https://doi.org/10.1038/nrd2757.

Plummer, P. J., and A. Krull. 2017. Clinical perspectives of digital dermatitis in dairy and beef cattle. Vet. Clin. North Am. Food Anim. Pract. 33(Suppl.1):165-181. https://doi.org/10.1016/j.cvfa .2017 .02 .002
Rasmussen, M., N. Capion, K. Klitgaard, T. Rogdo, T. Fjeldaas, M. Boye, and T. K. Jensen. 2012. Bovine digital dermatitis: Possible pathogenic consortium consisting of Dichelobacter nodosus and multiple Treponema species. Vet. Microbiol. 160:151-161. https:// doi.org/10.1016/j.vetmic.2012.05.018.

Rebhun, W. C., R. M. Payne, J. M. King, M. Wolfe, and S. Berg. 1980. Interdigital papillomatosis in dairy cattle. J. Am. Vet. Med. Assoc. 177:437-440.

Sánchez, E., R. Borja, P. Weiland, L. Travieso, and A. Martín. 2000. Effect of temperature and $\mathrm{pH}$ on the kinetics of methane production, organic nitrogen and phosphorus removal in the batch anaerobic digestion process of cattle manure. Bioprocess Eng. 22(Suppl. 1):0247-0252. https://doi.org/10.1007/s004490050727.

Tominaga, M., M. J. Caterina, A. B. Malmberg, T. A. Rosen, H. Gilbert, K. Skinner, B. E. Raumann, A. I. Basbaum, and D. Julius. 1998. The cloned capsaicin receptor integrates multiple pain-producing stimuli. Neuron 21:531-543. https://doi.org/10.1016/S0896 $-6273(00) 80564-4$

Tóth, B. I., A. Oláh, A. G. Szöllösi, and T. Bíró. 2014. TRP channels in the skin. Br. J. Pharmacol. 171:2568-2581. https://doi.org/10 $.1111 /$ bph. 12569 .

Warnick, L. D., D. Janssen, C. L. Guard, and Y. T. Gröhn. 2001. The effect of lameness on milk production in dairy cows. J. Dairy Sci. 84:1988-1997. https://doi.org/10.3168/jds.S0022-0302(01)74642 -5 . 